\title{
Undergraduates Innovative Training in Environmental Program
}

\author{
Yubo Cui ${ }^{\mathrm{a}}$, Chunqiu Ran ${ }^{\mathrm{b}}$, Hongjie Sun ${ }^{\mathrm{c}}$ and Xuejun Zou ${ }^{\mathrm{d}}$ \\ College of Environment and Resources, Dalian Nationalities University, Dalian, 116600, China

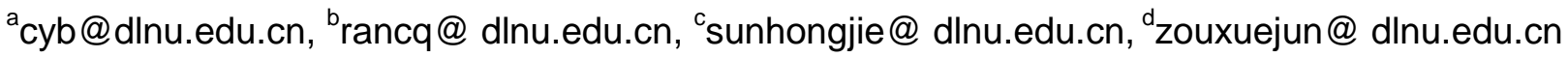

Keywords: Teaching University; environmental science; environmental engineering; training of innovative talents

\begin{abstract}
The main purpose of teaching university is to educate full-time undergraduates, popularize higher education and train high-level skilled talents and advanced research-based reserve talents. However, it's an urgent task to cultivate undergraduates equipped with innovative spirit and abilities when confronted with the needs of creativity and knowledge in modern society. Environmental sciences are emerging hybrid disciplines. With its content and policy ever changing so quickly, opportunities and challenges are waiting ahead in the education of undergraduates in order to meet the social requirement. Taking Dalian Nationalities university for instance, this paper introduces a project of cultivating creative talents in environmental engineering and environmental science, concludes a training mode centered by class teacher and teaching content composed of basic training module, internship training module and innovative training module. Besides, to ensure the cultivation of innovative talents and development of individualization, flexible educational administration and policy should be guaranteed.
\end{abstract}

\section{Introduction}

Environmental sciences are emerging hybrid disciplines. Its knowledge hierarchy, technology and needs change fast as times and policies develop. Especially today, higher requirements are posed to environmental talents in an age of information and environment internationalization. It is an urgent task for teaching university to combine teachers' role more efficiently and train environmental undergraduates adapting to the social needs [1]. This paper discusses the training mode of innovative talents in environmental engineering and science in teaching university according to the strategy of Dalian Nationalities University.

\section{The classification of Universities in China}

At present, there are more than 2300 universities and colleges qualified in common higher education in China. Basically accepted is the hierarchy of modern university. A relatively consistent view is to divide all the universities into four types according to their research degree and number of undergraduates, namely, researching university, teaching and researching university, teaching university and professional university.

The first type is researching university. Elite education, postgraduates are the main educational group. Scientists, social activists, various kinds of high-level experts will come from here. It focuses on the dissemination, production and application of innovative knowledge, aims to output high-level scientific achievements and talents and makes a lot of contribution to the social development, economic construction, culture prosperity and social safety in China.

The second is teaching and researching university. To train high-level developing talents of application technology is its goal. It is a common expression instead of an accurate concept, staying between the researching university and teaching university. As to its category, there is neither national uniform criterion nor agreeable view in academia. In general, teaching and researching university mainly cultivates technical talents doing well in designing and plays a major role in the transformation from "principle" to "program". It emphasizes broad knowledge, adaptability and excellent comprehensive quality, tries to train high-level talents with a complexity of knowledge, a pioneering spirit and research potential specialized in technology development and application. It is a significant 
transformation base for regional, local and industrial scientific achievements, showing a strong capability in certain areas.

The third is teaching university. It mainly recruits undergraduates, fulfills the functions of teaching, researching and training of talents, cultivates advanced technical talents and research-based reserve talents. It has the right to grant bachelor's degree and a small amount of master's degree and can enroll a certain number of junior college students. Teaching university has distinctive characteristics compared to researching university, such as taking full-time undergraduates' education as a main purpose, strong social adaptability, emphasizing the training of compound talents, a regional advantage and notable schooling benefits.

The fourth type is professional university, which is represented by vocational and technical college. Its main purpose is to train a group of talents with certain skills and college knowledge based entirely on secondary education. Te imparting of knowledge is utmost practical-oriented.

\section{Innovative Training of Environmental undergraduates in Teaching University}

Higher requirements are proposed to teaching university as the implementation of reforms in national education system and improving projects of innovation and quality in talents' training mode. Dalian Nationalities University has explored a training mode concerning its own schooling orientation, teacher resources and students' quality after years of efforts, this mode meets the development needs of educational situations both at home and abroad. The Details are reflected below.

\subsection{All-staff Taking Part in Education}

Traditionally, ideological and political education plays an important role in Chinese college education. Every university has a number of instructors responsible for ideological and political education. However, the instructors have been stressed out as the enrollment amount and the proportion degree of one-child per family continue to increase. Moreover, the affection of single ideological and political education is showing a downward trend. Consequently, college students need to be trained by professional teachers combining professional practice, through which ideological and political education can be unconsciously pulled out. Remarkable success has been achieved since the overall implementation of class teacher system in Dalian Nationalities University.

In class tutor system, every class unit of every major is in the charge of one tutor who has rich experience in the professional area. These tutors are responsible for instructing the students in major courses, scientific research and career planning based on their professional advantages and reform practice of the credit system. They improve the students' learning awareness, employment awareness and crisis awareness and guide them to construct knowledge structure scientifically, establish career direction, cultivate professional skills and expand personal advantages [2].

Class tutor system helps a lot in students' postgraduate exam, employment, studying abroad and comprehensive quality and trains a group of tutors who is firm in ideal, decisive in work style and perfect in business affairs. $100 \%$ of teachers once worked as a class tutor and some is still on service in environmental major. Meanwhile, professional teachers actively apply for scientific projects with respect to ideological and political education, which has covered $50 \%$ of professional teachers exploring in this field. These projects not only promote the theoretical level of the tutors, but also give fresh meanings to environmental sciences. They provide a powerful warranty with the construction of special majors and cultivation of college students.

\subsection{Training System Establishment of Innovative Talents}

\subsubsection{Basic training module}

The basic curriculum frame is reserved and some professional selective courses are suitably opened in accordance with the professional construction guidance documents of the National Environmental Education Steering Committee. An evident feature is that every relevant experiment part has an independent course. Besides, a two-week comprehensive experiment course is prepared when all the major courses are finished. The two-week special course covers three parts: creative 
experiment with a certain technology content, comprehensive experiment inclining to the integrity of professional knowledge, designing experiment emphasizing students' independent operation. Some standard methods are ready to be assimilated by the students during the experiment parts, which will certainly pave the way for their employment in monitoring works and help them adapt to the working conditions quickly and stand out in future competitions [3-4].

Taking full account of the practicing system and exam needs of national registration Environmental Impact Assessment Engineer and Environmental Protection Engineer, many relevant subjects are opened either compulsively or selectively for students to choose freely. Integrate bilingual teaching is taken in all curriculum; that is to say, train the students' English proficiency through English vocabulary, English homework, English experiment reports and English papers. Broaden their minds and horizon by introducing industrial policies and trends both at home and abroad.

\subsubsection{Practice training module}

This segment gives the students a chance to connect and understand the society and working conditions in the future. It has three training areas: operation ability, comprehensive ability of major knowledge and problem-solving ability. As a result, the construction of exercitation base is always highly valued. In the process of education and teaching, social force are introduced actively, for instance, twelve practice agreements have been signed between environment major and outer enterprises. College education is refined in the practice process and "order" training is partly realized by the enhanced fostering of certain links concerning the needs of the enterprises [5].

Furthermore, the teaching program is adjusted in time based on students' actual situation in taking part in the entrance exams for postgraduate schools and employment. For example, all the theoretical courses of the seventh term are compressed into the first eight weeks while the left time is arranged for comprehensive experiment, course design and practice. Thesis proposal is also brought forward to the seventh term. In fact, students are diverted by their needs in this way, thus they pay attention to their main task: preparing thesis, taking part in practice or preparing exam for advanced education. This multi-level teaching program optimizes the study time, values the main study contents and ensures the teaching effects.

\subsubsection{Innovative training module}

Taking innovative workshops and laboratories as a platform, a package of creative training systems has formed with the support of "Sun Bird" scientific research and elaborate experiments and teachers' research projects. Under the training mode of academic and professional integration, school and enterprise cooperative education, we developed the effective paradigm for students' innovation ability cultivation, i.e. curricular and extracurricular integration + practice base, innovative studio and laboratory collaborative practice. Part of students participate in innovation projects and innovative studio courses, all students participate excellent experiment item and comprehensive experiment projects, resulting in the new pattern formation of stimulating students' innovation ability training [6-7].

At present, there are 12 laboratories and 4 innovative studios in the department of environmental engineering, Dalian Nationalities University, which has the capacity of 120 students each year, ensuring the cultivation of undergraduates. Every student is allowed into the studios regardless of their grade. "Inverted" professional practice training will be carried out for the students who are admitted into the innovative groups early [8-9]. The training will lay firm foundation for theory learning in the future.

Achievement of innovative education mainly covers competition awards, published papers, declared patents and so on. In the near five years, the achievements of students are listed in Table 1.

The students' self education and training program got significant results preliminarily. "Huaxin Lihua Company Cup” Environmental Protection Works Competitions were hold in 2014 and 2015, forming a student oriented organizational mode, i.e. corporate sponsorship - student organization teacher guidance mode, students representative from more than ten universities participated the 
competition activity, which exercise student organization ability and team cooperation ability. At the same time, it enlarged the impact of the university [10].

Table 1 Student achievements of innovative education

\begin{tabular}{|c|c|c|c|}
\hline Item & Level & Number & Students \\
\hline \multirow[t]{2}{*}{ Competition awards } & Province & 38 & 60 \\
\hline & National & 12 & 478 \\
\hline \multirow[t]{2}{*}{ Undergraduates' innovative undertaking project of China } & Province & 27 & \\
\hline & University & 75 & \\
\hline $\begin{array}{l}\text { "Sun Bird" undergraduates' research project in the } \\
\text { university }\end{array}$ & University & 144 & 403 \\
\hline Participate teacher’s research project & - & $>20$ & $>200$ \\
\hline Published paper & - & 106 & 445 \\
\hline Declared patent & National & 65 & 162 \\
\hline
\end{tabular}

\subsubsection{Creative Educational Administration}

The Office of Academic Affairs in Dalian Nationalities University takes flexible administration policies in order to ensure the training of innovative undergraduates, such as college-enterprise joint training, practice directly connected with enterprises, etc. Meanwhile, a series of protective measures are adopted, such as purchasing insurance for the students taking part in practice and allocating instructors from both sides and so on. Besides, a month of productive practice can substitute for 2 credits, students with academic achievement has the chance to be awarded the prize of Excellent Academic Achievement [11]. These policies have explored an efficient way for the individualization cultivation of undergraduates.

\section{Conclusions}

Teaching university has its own characteristics and orientations. However, how to adapt to the society which praises highly of learning and innovation and training a group of undergraduates with powerful competitiveness is still a difficult problem to be solved. After introducing the training mode of innovative and environmental talents in Dalian Nationalities University, a few conclusions are drawn as follows:

The cultivation of creativity should be an evaluation indicator of an eligible undergraduate in teaching university.

The training of innovative talents can be efficiently guaranteed by proper setting of basic training module, practice raining module and innovative training module.

All-staff taking part in education is an essential part in training of innovative talents; professional teachers need to take more efforts.

To ensure the training process, the Office of Academic Affairs should adopt flexible administration policies and encourage diversity and individualization positively.

\section{Acknowledgment}

This work was supported by The Educational Assessment Foundation of Liaoning Province (No. PJHYYB15052), the Education Reformation Foundation of National Commission on Ethnic Affairs of China (No.15042), Educational Scientific Planning Project of Liaoning Province (No. JG15DB07 4), Teaching Reform Project of Liaoning Province (2016).

\section{References}

[1]. X. R. Wang, “Advance Creation Education and Train Creation Teacher,” Journal of Changchun Education Institute, vol. 26, pp. 10-11, February 2010. 
[2]. Y. B. Cui, X. Y. Ang and L. Z. Liu, "Environmental Engineering Education in University in China," Proceedings of the 3rd International Conference on Environmental Technology and Knowledge Transfer. Hefei, China, pp. 861-864, 2010

[3]. S. H. Lan, H. B. Fan and X. W. Wu. "Reformation and Practice of Practice Education System for Environmental Engineering Specialty.” Journal of Dongguan University of Technology, vol. 18, pp. 109-113, May 2011.

[4]. Q. J. Xie and W. H. Huang, "Improving Measurement for Environmental Engineering Undergraduate Design or Thesis.” Scientific Information, vol. 36, p.284, August 2008.

[5]. T. Sui and J. J. Liu, “The Teaching Reform of Environmental Engineering about the Course Design for A Plan for Education and Training of Outstanding Engineer.” Value Engineering, vol. 28, p. 181, June 2011.

[6]. Y. B. Cui, C. Q. Ran, B. D. Zhao and X. C. Wang, "Environmental student innovative Education in Teaching University .” Journal of China Electronic Education, 5, pp. 32-33, May 2012.

[7]. X. J. Zou, Y. B. Cui, , Y. Y. Dong and C. Q. Ran, "Study on the operation and management mechanism of the external practice base of Environmental Engineering Specialty.” Journal of China Electronic Education, 29, pp. 91-92, November 2014.

[8]. Y. B. Cui, , D. X. Hu and C. Q. Ran, "Environmental pollution control technology innovation studio school-based curriculum construction .” Journal of China Electronic Education, vol. 5, pp. 124-125, October 2013.

[9]. Y. B. Cui, H. J. Sun and C. Z. Chen, “ Comprehensive reform of Environmental Specialty.” Journal of China Electronic Education, 9, pp. 77-78, September 2013.

[10]. Y. B. Cui, B. D. Zhao and H. J. Sun, “Theoretical exploration of extracurricular professional education .” Journal of China Electronic Education, 9, pp. 13-14, September 2010.

[11]. Y. B. Cui, B. D. Zhao and H. J. Sun, “ Comparison of environmental engineering in High Education between China and Canada ." Research on educational innovation and management of Ethnic Higher Education Institutions, pp. 52-54, April 2011. 